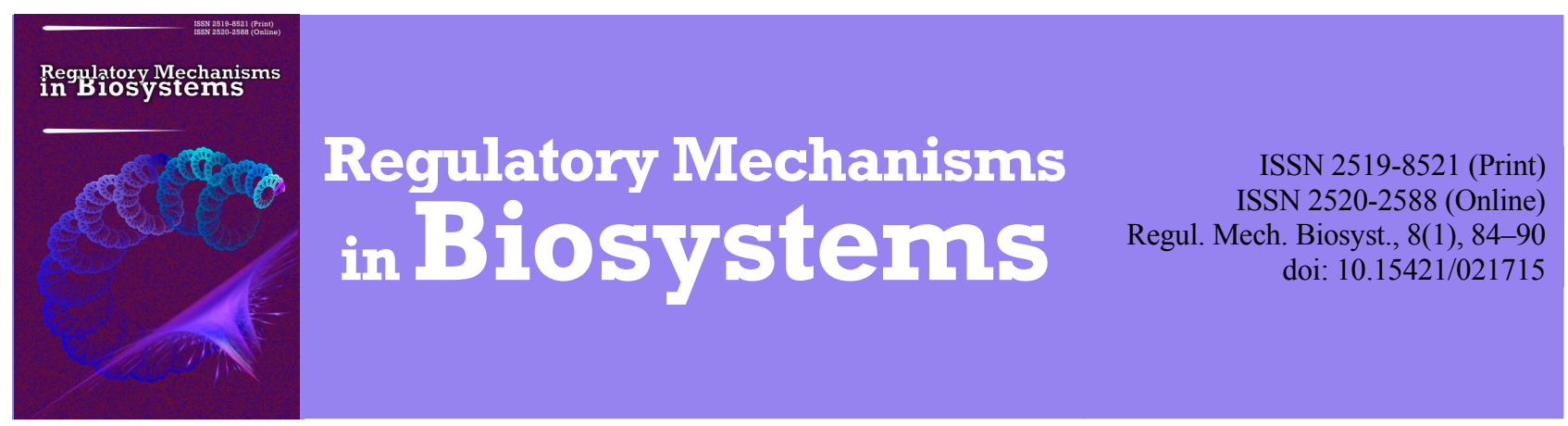

\title{
Mutual influence of intensity of pain syndrome and borderline mental disorders in patients with coxarthrosis
}

\author{
I. D. Spirina, E. S. Fedenko, S. V. Rokutov, V. Y. Kazakov, A. V. Shornikov \\ Dnipropetrovsk Medical Academy of Health Ministry of Ukraine, Dnipro, Ukraine
}

Article info

Received 12.12.2016

Received in revised form 02.02.2017

Accepted 15.02.2017

Dnipropetrovsk Medical Academy of Health Ministry of Ukraine, V. Vernadsky Str., 9 , Dnipro, 49044, Ukraine Tel.: +38-067-104-43-69 E-mail:psychiatry@dma.dp.ua
Spirina, I. D., Fedenko, E. S., Rokutov, S. V., Kazakov, V. Y., \& Shornikov, A. V. (2017). Mutual influence of intensity of pain syndrome and borderline mental disorders in patients with coxarthrosis. Regulatory Mechanisms in Biosystems, 8(1), 84-90. doi: 10.15421/021715

The objective of this study is to evaluate the mutual influence of pain syndrome and borderline psychiatric disorders depending on its intensity and tolerability in patients with coxarthrosis who need endoprosthetics. 76 patients with coxarthrosis aged from 25 to 68 who were hospitalized in the Department of Endoprosthetics at Mechnikov Regional Clinical Hospital in Dnipro City in the period from November 2015 to September 2016 were observed. For diagnosis of psychopathological disorders, and for evaluation of the effectiveness of therapeutic interventions, the following methods were used in our research: clinical and psychopathological (technique SCL-90-R), Taylor anxiety scale, study of the type of attitude to the disease (LOBI), Dembo-Rubinstein self-esteem scale, Leonhard-Schmieschek questionnaire for assessment of accentuation of personality traits, the Luscher 8-colour test and the Toronto alexithymia scale (TAS). Severity of pain syndrome was assessed using a visual analogue scale of pain (VAS). Forms of borderline mental disorders were diagnosed in 51 patients with coxarthrosis, such as depressive disorder (F 32) - 19 (24.8\%), neurasthenia (F 48) - 12 (16.2), anxiety and phobic disorders ( F 40-41) - 14 (18.1\%), and personality disorders ( F 60.5, F 60.6, F 60.7) - 6 (7.6\%). In 25 (33.3\%) patients clinically-defined forms of mental disorders were identified. Leading syndromes in these disorders were depression - $19(24.8 \%)$ patients, anxiety and phobic $-15(20.0 \%)$, asthenic - 10 (12.4\%), hypochondriacal - $7(9.5 \%)$ patients. According to the results of the correlation analysis, a close correlation between the severity of pain syndrome and borderline mental disorders $(r=0.779)$ was established for patients in the preoperative stage. The average level of pain syndrome on the VAS scale in patients with borderline mental disorders was twice as high as in patients without these disorders (63.4 vs. 32.4 points), but it does not depend on the main psychopathological syndrome. The average level of pain on the VAS scale in patients with borderline mental disorders at the preoperative stage was twice as high as in patients without these disorders (63.4 vs 32.4 points), and after surgical intervention the level decreased only by 5.9 points or $9.3 \%$. In patients with coxarthrosis with detected borderline mental disorders (51 people) the therapy had a complex character and was conducted both at the hospital stage for one month, and in the outpatient stage as "maintenance" therapy for 3 months or more. Therapy of the neurotic state with decompensation lasted on average 6 months. Treatment included psycho-educational and therapeutic arrangements (conversations, lectures, autotraining) and psychopharmatherapy (tranquilizers, antidepressants, antipsychotics in small and medium therapeutic doses). The conducting of simultaneous corrective measures for identified borderline mental disorders in patients of the main groups contributed to a significant reduction in the severity of pain within the sixmonth period of observation and moved them towards the level of the patients in the control group. Borderline mental disorders that take place in patients with chronic somatic diseases, which include, in particular, coxarthrosis, significantly amplify the severity of the condition, reduce the possibility of adaptation, and thus aggravate the course and the outcome of the main disease.

Keywords: pain; nonpsychotic mental disorders; coxarthrosis; psychopathological disturbances

\section{Взаємовплив інтенсивності больового синдрому та граничних психічних розладів у хворих на коксартроз}

\author{
І. Д. Спіріна, Є. С. Феденко, С. В. Рокутов, В. Є. Казаков, А. В. Шорніков
}

Державний заклад «Дніпропетровська медична академія» МОЗ України, Дніпро, Україна

Оцінено взаємовплив больового синдрому та граничних психічних розладів залежно від його інтенсивності та переносимості у хворих на коксартроз, які потребують ендопротезування тазостегнового суглоба. Спостерігали 76 хворих на коксартроз віком 25-68 років, які перебували на стаціонарному лікуванні у відділенні ендопротезування обласної клінічної лікарні ім. І. І. Мечникова м. Дніпро у період із листопада 2015 по вересень 2016 року. Для діагностики психопатологічних розладів і оцінювання ефективності лікувальних заходів у 
роботі застосовано такі методи: клініко-психопатологічний (методика SCL-90-R), шкала тривоги Тейлора, дослідження типу ставлення до хвороби (ЛОБІ), шкала самооцінки Дембо - Рубінштейн, опитувальник Леонгарда - Шмішека, 8-колірний тест Люшера, Торонтська алекситимічна шкала (TAS). Вираженість больового синдрому оцінювалась за допомогою візуально-аналогової шкали болю (ВАШ). Під час дослідження у 51 хворого на коксартроз діагностовано такі форми граничних психічних розладів як депресивний розлад (F 32) - 19 (24,8\%), неврастенія (F 48) - 12 (16,2\%), тривожні та фобічні розлади (F 40-41) - 14 (18,1\%), розлади особистості (F 60.5, F 60.6, F 60.7) - 6 $(7,6 \%)$. У $25(33,3 \%)$ пацієнтів клінічно окреслених форм психічних розладів не виявлено. Провідні синдроми при цих розладах: депресивний - 19 хворих (24,8\%), тривожно-фобічний - 15 (20,0\%), астенічний - 10 (12,4\%), іпохондричний - 7 пацієнтів $(9,5 \%)$. За результатами кореляційного аналізу встановлено тісну кореляцію вираженості больового синдрому з наявністю граничних психічних розладів $(\mathrm{r}=0,779)$ на передопераційному етапі. Середній рівень больового синдрому за ВАШ у хворих із граничними психічними розладами вдвічі вищий, ніж у пацієнтів без цих порушень (63,4 проти 32,4 бала), але не залежав від провідного психопатологічного синдрому. Середній рівень інтенсивності болю за ВАШ у хворих із виявленими граничними психічними розладами на передопераційному етапі був удвічі вищий, ніж у пацієнтів без цих порушень (63,4 проти 32,4 бала), а після оперативного втручання показник зменшився лише на 5,9 бала, або 9,3\%. Одночасне проведення корекційних заходів щодо виявлених граничних психічних розладів у хворих основної групи дозволило вже до шестимісячного строку спостереження суттєво зменшити вираженість больового синдрому та наблизити їх до рівнів пацієнтів контрольної групи. Граничні психічні порушення у хворих із тривалими соматичними захворюваннями, до яких, зокрема, належить коксартроз, суттєво посилюють тяжкість стану, знижують адаптаційні можливості, обтяжуючи перебіг і результат основного захворювання.

Ключові слова: біль; психічні розлади; коксартроз; психопатологічні розлади

\section{Вступ}

Тазостегновий суглоб - найважливіший елемент опори та пересування людини у просторі, що має широкі функціональні можливості, випробовує значні статичні та динамічні навантаження та забезпечує гармонійність рухів людини (Loskutov, 2010). Дегенеративно-дистрофічні захворювання суглобів (остеоартроз, артроз, остеоартрит) належать до найпоширеніших форм ураження опорно-рухового апарату у дорослого населення багатьох країн, включно з Україною (Loskutov, 2010; Nassonova et al., 2011; Zagorodniy, 2011; Ackerman et al., 2017). Остеоартроз посідає провідну позицію серед усіх ревматичних захворювань (60-70\%), а його клінічні симптоми спостерігаються у 10-20\% дорослого населення (Poulsen et al., 2012; Cho et al., 2015).

Найбільш доказовими факторами ризику розвитку та прогресування остеоартрозу вважають вік, жіночу стать, надлишкову масу тіла, обтяжену спадковість (Tukker et al., 2008; Lawrence et al., 2008; Nassonova et al., 2011; Hardcastle et al., 2014; $\mathrm{Kc}$ et al., 2015). Серед хворих на остеоартроз у молодому віці переважають чоловіки, у похилому - жінки. Захворювання зазвичай маніфестує в осіб віком понад 40 років та виявляється у $30-40 \%$ осіб віком до 65 років і у $50-90 \%$ - понад 65 років (Makolkin et al., 2007; Sharma and Berenbaum, 2007). Останні роки характеризуються тенденцією до зростання захворюваності на остеоартроз як у результаті загального постаріння населення, так і за рахунок розвитку захворювання в осіб молодше 45 років.

Значне поширення дегенеративно-дистрофічних захворювань серед дорослого населення та їх прогресуючий перебіг спричинюють втрату працездатності, а також передчасну інвалідність, що перетворює медичну реабілітацію таких хворих на важливу проблему охорони здоров'я (Loskutov, 2010). Соціальна значущість остеоартрозу зумовлена такими характеристиками захворювання: хронічним прогресуючим перебігом, рецидивуючим больовим синдромом, наростаючим обмеженням рухової функції та свободи пересування, необхідністю проведення тривалого (нерідко довічного) високовартісного лікування (Loskutov, 2010; Nassonova et al., 2011; Mújica Mota, 2013). Причому соціальні аспекти захворювання з розвитком цивілізації, урбанізації й технічним прогресом усе більше зростають, а групи ризику серед населення збільшуються, чому сприяє хронічний стрес, погіршення екології, аутоімунні реакції, гіподинамія тощо. За даними американських дослідників, очікується, що в наступні два десятиліття захворюваність на остеоартроз збільшиться більше ніж удвічі (Lawrence et al., 2008). Прогнозоване до 2020 року збільшення тривалості життя населення Землі висуває остеоартроз на четверте місце серед провідних причин втрати працездатності населення (Zagorodniy, 2011).

Коксартроз (КА) - хронічне прогресуюче захворювання тазостегнового суглоба - визнаний найважчою формою остеоартрозу та серйозною медико-соціальною проблемою у зв'язку зі значним поширенням хвороби серед осіб працездатного віку, втратою професійних і соціальних навичок, значною інвалідизацією хворих, неминучим зниженням якості життя (Loskutov, 2010; Zagorodniy, 2011). За даними вітчизняної та зарубіжної літератури, КА посідає перше місце серед аналогічних захворювань інших великих суглобів (Loskutov, 2010). На захворювання даної локалізації страждають 30-50\% хворих остеоартрозом (Zagorodniy, 2011), 3-5\% усього населення (Zagorodniy, 2011; Cho et al., 2015), а інвалідність становить 7,0-37,6\% кількості всіх інвалідів 3 ураженнями опорнорухової системи (Duffy et al., 2005). В Україні серед хворих, що вперше звернулись до медико-соцільної експертної комісії (МСЕК) для встановлення групи інвалідності у зв'язку 3 патологією опорно-рухового апарату, пацієнти з КА складають близько 35\% (Chaban and Khaustova, 2010).

Біль виступає першим і основним симптомом захворювання, входить до діагностичних критеріїв остеоартрозу основних локалізацій - кисті, тазостегнового та колінного суглобів (Chong et al., 2013; Rahman et al., 2016). Міжнародна асоціація 3 вивчення болю (IASP) визначає його як «неприємне сенсорне й емоційне переживання, пов'язане 3 істинним або потенційним пошкодженням тканини або описуване у термінах такого пошкодження» (Rebrov et al., 2011). Це свідчить, що відчуття болю може виникати навіть за відсутності будь-якого пошкодження, але описуватися пацієнтом як відчуття пошкодження. Тобто біль завжди суб'єктивний, що вказує на важливу роль психічних чинників у формуванні та підтриманні болю. Саморегуляція болю та його вплив на організм багато в чому залежать від того, як саме люди справляються з болем, адаптуються до нього та мінімізують стрес, зумовлений болем, тобто від їх стратегій психофізіологічної адаптації (Bair et al., 2008; Munce and Stewart, 2007).

Гострий і хронічний біль потрібно розглядати як найактуальнішу проблему охорони здоров'я. Гострий біль звичайно вказує на конкретну проблему чи загрозу для життя, у той час як хронічний біль $€$ в усіх випадках патологічним станом, який викликає дезадаптацію та зниження якості життя пацієнта (Danilov et al., 2010). Загальновизнані факти, що виражені психопатологічні зміни часто супроводжують хронічний больовий синдром. Доведено також участь цих змін у патогенезі больового синдрому та їх негативний вплив на ефективність лікування (Chaban and Khaustova, 2010; Rebrov et al., 2011). Для хронічного болю характерні зміни симпатичної активності й розвиток стійких вегетативних симптомів, у тому числі зниження апетиту, загальне нездужання, розлади сну, роздратованість, а його психологічні складові часто характеризуються депресією, страхом та іншими афективними розладами (Munce and Stewart, 2007; Rebrov et al., 2011).

Найпоширенішими психічними розладами, що часто поєднуються із соматичними хворобами, вважають тривогу та депресію (Strine et al., 2008; Beltman et al., 2010; O'Connor et al., 2015; Bokma et al., 2017). Зокрема, серед хворих на остеоартроз похилого віку (старше 60 років) поширеність депресивних синдромів дуже висока (82,4\%) (Sale et al., 2008; Hawker et al., 
2011; Matcham et al., 2014; Rodic et al., 2015). При цьому можливі як соматопсихічні, так і психосоматичні взаємовідносини між цими захворюваннями. Маючи спільні ланки патогенезу на тлі зниженого індивідуального адаптаційного бар'єру до впливу різноманітних психогенних факторів, соматичне захворювання може бути безпосередньою причиною тривожнодепресивних розладів або прискорювати їх розвиток. Так само як і високий рівень тривожності та депресія супроводжуються вираженими порушеннями функції органів та систем організму, негативно впливають на перебіг соматичної хвороби, порушуючи суб'єктивне сприйняття хворим іï динаміки та знижуючи ефективність лікувально-реабілітаційних заходів (Riediger et al., 2010; Sharma et al., 2016).

За даними численних досліджень, депресія поєднується із хронічним болем у $11-50 \%$ випадків і супроводжується посиленням болю, зниженням якості життя, підвищенням інвалідності та вартості лікування (Munce and Stewart, 2007; Bair et al., 2008; Calvo-Lobo et al., 2017). При цьому як депресія, так i хронічний біль у жінок спостерігаються частіше, ніж у чоловіків (Bair et al., 2008; Tonelli et al., 2011). Субклінічні прояви депресії у хворих із хронічним болем зумовили відповідну термінологію: «прихована», «маскована», «ларвована», «атипова», «алекситимічна» тощо. Деякі автори вважають, що в усіх випадках хронічного больового синдрому має місце депресія. Вони грунтуються на тому факті, що біль завжди супроводжується негативно-емоційними переживаннями та блокує можливість людини одержувати радість і задоволення (Chaban and Khaustova, 2010). Найбільші суперечки викликає не сам факт співіснування хронічного болю 3 депресією, а причинно-наслідкові відносини між ними. Тривалий біль обмежує професійні й особистісні можливості людини, примушує ії відмовлятися від звичних життєвих стереотипів, порушує ії життєві плани тощо. У свою чергу, зниження якості життя сприяє формуванню вторинної депресії. Встановлено, що у пацієнтів із хронічним болем і депресією біль має більшу інтенсивність $\mathrm{i}$ зберігається довше після операції з ендопротезування ураженого суглоба. Такі хворі частіше використовують пасивні стратегії подолання болю, мають низьку самооцінку та нижчу якість життя (Bair et al., 2008).

Діагностика психопатологічних порушень у пацієнтів із соматичними захворюваннями, включно 3 тими, що супроводжуються хронічним больовим синдромом, у наш час базується на використанні біопсихосоціальної моделі. На відміну від біомедичної моделі, яка робить акцент тільки на захворюванні, біопсихосоціальна модель фокусується і на захворюванні, i на розладі, на комплексній взаємодії біологічних, психологічних і соціальних змінних (Chaban and Khaustova, 2010; Rebrov et al., 2011). Біологічні чинники можуть ініціювати, підтримувати та модулювати фізичні порушення, тоді як психологічні змінні впливають на оцінку та сприйняття внутрішніх фізіологічних ознак, а соціальні чинники формують поведінкові реакції пацієнтів на переживання фізичних порушень. На різних стадіях прогресування захворювання або розладу відносна важливість фізичних, психологічних і соціальних чинників може зміщуватися. Проте жоден окремо взятий чинник не може вважатися винятковою причиною глибокої особистісної декомпенсації. Лише їх спільна дія зумовлює злам біологічної, індивідуальнопсихологічної та соціальної ланок адаптації (Bair et al., 2008), що стає причиною психічного розладу.

Мета дослідження - оцінка взаємовпливу больового синдрому та граничних психічних розладів залежно від його інтенсивності та переносимості у хворих на коксартроз, які потребують ендопротезування тазостегнового суглоба.

\section{Матеріал і методи досліджень}

Ми спостерігали 76 хворих на коксартроз (КА) у віці 2568 років, які перебували на стаціонарному лікуванні у відділенні ендопротезування обласної клінічної лікарні ім. І. І. Меч- никова м. Дніпро у період із листопада 2015 по вересень 2016 року. Серед обстежених 27 (36,2\%) чоловіків і 49 (63,8\%) жінок, середній вік - 51,3 року (табл. 1).

Критерії включення пацієнтів у дослідження: хворі на КА віком від 18 років, яким проведено ендопротезування тазостегнового суглоба, інформована згода на участь у дослідженні. Критерії виключення пацієнтів із дослідження: наявність психотичних психічних розладів, залежність від психоактивних речовин, онкологічні та дегенеративні захворювання.

Усі пацієнти страждали на КА, що підтверджено відповідними медичними документами. Всім хворим виконано оперативне втручання - ендопротезування тазостегнового суглоба.

Клініко-психопатологічний метод базувався на загальноприйнятих підходах до психіатричного обстеження пацієнтів i включав складові частини дослідження: опитування, зовнішній огляд, спостереження за поведінкою, аналіз об'єктивних ознак розладів або особливостей психічного стану. Відомості, отримані від пацієнта, об'єктивізувалися іншими даними, зокрема інформацією з медичної документації. Установлення діагнозу та верифікація клінічної форми психічного розладу проводились відповідно до критеріїв МКХ-10.

\section{Таблиця 1}

Демографічна характеристика пацієнтів із коксартрозом ( $\mathrm{n}=76)$

\begin{tabular}{cccc}
\hline \multirow{2}{*}{ Показники } & \multicolumn{2}{c}{ Кількість паціснтів } \\
\cline { 2 - 4 } Стать & чоловіча & 27 & $\mathrm{P}, \%$ \\
\hline \multirow{2}{*}{ жсс. } & 36,2 \\
& жіноча & 49 & 63,8 \\
\hline \multirow{2}{*}{ Вік, роки } & до 40 & 9 & 11,4 \\
& $41-50$ & 18 & 23,8 \\
& $51-60$ & 30 & 39,1 \\
& понад 60 & 19 & 25,7 \\
\cline { 2 - 4 } & середній, $\mathrm{M} \pm \mathrm{SE}$ & \multicolumn{3}{c}{$51,3 \pm 0,9$} \\
\hline
\end{tabular}

Для діагностики психопатологічних розладів і оцінювання ефективності лікувальних заходів у дослідженні використано симптоматичний опитувальник Symptomatic Check List 90 Revised (SCL-90-R), шкалу тривоги Тейлора, дослідження типу ставлення до хвороби (ЛОБІ), шкалу самооцінки Дембо Рубінштейн, опитувальник Леонгарда - Шмішека для оцінювання особистісної акцентуації, 8-колірний тест Люшера, Торонтську алекситимічну шкалу (TAS). Вираженість больового синдрому оцінювали за допомогою візуально-аналогової шкали болю (ВАШ) (0 - біль відсутній, 100 балів - нестерпний біль). Наявність больового синдрому об'єктивізували соматовегетативними проявами, такими як коливання артеріального тиску, прискорене серцебиття, підвищена пітливість.

\section{Результати}

За результатами клініко-психопатологічного дослідження та критеріями МКХ-10 у 51 (66,7\%) хворого на КА діагностували такі форми граничних психічних розладів (ГПР): депресивний розлад (F 32) - 19 (24,8\%), неврастенія (F 48) - 12 (16,2\%), тривожні та фобічні розлади (F 40-41) - 14 (18,1\%), розлади особистості (F 60.5, F 60.6, F 60.7) - 6 (7,6). У 25 $(33,3 \%)$ пацієнтів клінічно окреслених форм психічних розладів не виявили. Провідні синдроми за цих розладів: депресивний - 19 хворих (24,8\%), тривожно-фобічний - 15 (20,0\%), астенічний - 10 (12,4\%), іпохондричний - 7 пацієнтів $(9,5 \%)$. Провідною клінічною характеристикою у хворих на КА був біль, вираженість якого до оперативного втручання оцінювали в $53,0 \pm 1,7$ балів за візуально-аналоговою шкалою (ВАШ). Протягом дослідження не виявлено суттєвих зв'язків (Р >0,05) показника ВАШ як із соціально-демографічними характеристиками (стать, вік, освіта, сімейний стан, соціальний статус), так і з основними клінічними характеристиками КА (тривалість захворювання, характер ураження суглоба тощо) в цілому. Деякі відмінності відмічені у віковій групі до 40 років $(43,1 \pm$ 4,5 проти 54,3 $\pm 1,8$ бала у решті груп; $\mathrm{P}<0,05$ ) (рис. $1 a$ ). 
За результатами кореляційного аналізу встановили тісну кореляцію між вираженістю больового синдрому та наявністю ГПР ( $\mathrm{r}=0,779 ; \mathrm{P}<0,001)$ на передопераційному етапі. Середній рівень больового синдрому за шкалою ВАШ у хворих із ГПР удвічі вищий, ніж у пацієнтів без цих порушень $(63,4 \pm$ $1,3$ проти $32,4 \pm 1,5$ бала; $\mathrm{P}<0,001)$, але він не залежить від провідного психопатологічного синдрому. Коливання середнього балу болю склало від $62,0 \pm 2,1$ бала за депресивного синдрому до $65,3 \pm 2,4$ бала за тривожно-фобічного синдрому ( $>$ 0,40 для всіх порівнянь між групами за критерієм Дункана) (рис. 1б). Розвиток захворювання може утворити порочне коло: негативні емоції, пов'язані з болем, збільшують ступінь мимовільної м'язової напруги, що, у свою чергу, посилює больові відчуття. У результаті дослідження встановили, що больовий синдром суттєво посилювався $(\mathrm{P}<0,001)$ за підвищеної тривожності $(\mathrm{r}=0,471)$, вираженості депресивної симптоматики $(\mathrm{r}=0,529)$, астенічних проявів $(\mathrm{r}=0,652)$, наявності особистісної акцентуації $(\mathrm{r}=0,611)$, переважання неврастенічного $(\mathrm{r}=0,473)$, іпохондричного $(\mathrm{r}=0,359)$ і тривожного $(\mathrm{r}=0,348)$ типів ставлення до хвороби, вираженості алекситимічного радикала ( $\mathrm{r}=$ $0,382)$, за зниженої самооцінки рівня здоров'я $(\mathrm{r}=-0,514)$ та соціального функціонування $(\mathrm{r}=-0,259 ; \mathrm{P}<0,01)$ (рис. 2 ).

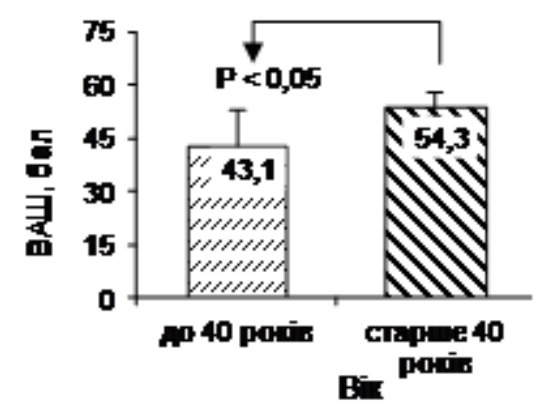

$a$

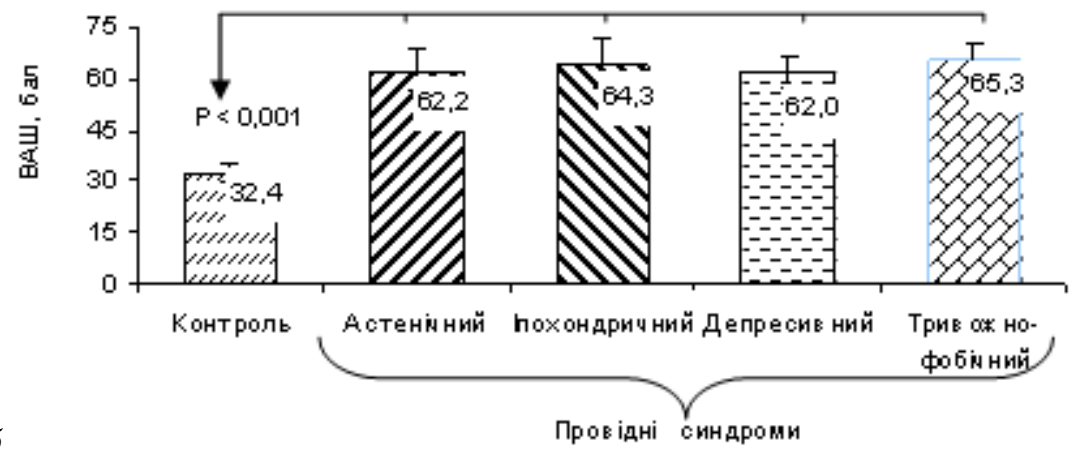

Рис. 1. Середній рівень проявів больового синдрому за ВАШ залежно від віку $(a)$ та вираженості психопатологічної синдроматики (б): $\mathrm{P}$ - за критерієм Даннета ( $\mathrm{n}=76)$
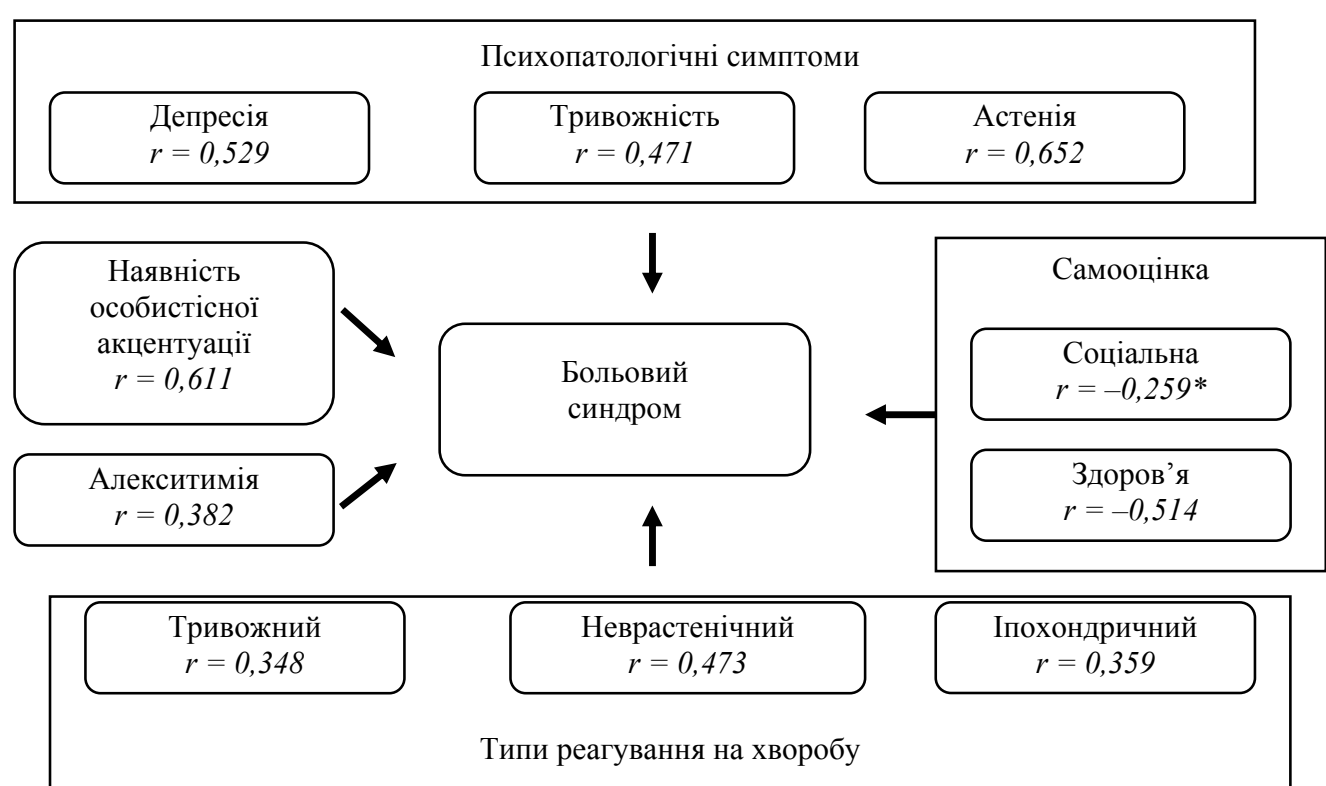

Рис. 2. Кореляційний взаємозв'язок вираженості больового синдрому з окремими клінічними та психологічними чинниками у хворих на коксартроз: $r$ - коефіцієнт кореляції Спірмена; * $-\mathrm{P}<0,01$, в інших випадках $-\mathrm{P}<0,001$

Аналіз структури та генезису ГПР у хворих на КА свідчить про складність взаємодій соматичних, психогенних і конституційних особливостей хворих. Із цього приводу в кожному конкретному випадку необхідно оцінювати питоме значення всіх факторів у структурі хвороби для адекватного застосування психофармакологічних та психотерапевтичних засобів лікування. До основних вимог до психофармакотерапії психосоматичних розладів належать: широкий спектр психотропної активності: ефективний вплив на тривожні, депресивні, іпохондричні, астенічні та алгічні розлади; мінімальна негативна дія на соматичні функції; виражені соматотропні (терапевтичний вплив на супутню соматичну патологію) та соматовегетативні ефекти; мінімальна поведінкова токсичність (незначна вираженість або відсутність седативних ефектів - сонливості в денний час, порушення уваги тощо). Виходячи із принципів терапії ГПР, які застосовуються в сучасній психіатрії, ком- плексна терапія невротичних розладів набуває великого значення при співвідношенні біологічних (лікарських) і соціотерапевтичних (в основному психотерапевттичних) методів. Тому лікування включало психоосвітні та психотерапевтичні заходи (бесіда, лекція, аутотренінг), а також психофармакотерапію (транквілізатори, антидепресанти, нейролептики в малих i середніх терапевтичних дозах).

У хворих на КА 3 виявленими граничними психічними розладами (51 особа) терапія мала комплексний характер і проводилась як на госпітальному етапі протягом одного місяця, так і на амбулаторному етапі у вигляді «підтримувальної» терапії упродовж трьох місяців та більше. Терапія невротичного стану 3 декомпенсацією триваліша, у середньому 6 місяців.

Динаміку вираженості клініко-психопатологічної симптоматики у хворих на КА з виявленими ГПР за впливу комплексної психотерапевтичної та психофармакологічної терапії 
оцінювали за даними психіатричного обстеження 3 використанням стандартизованого опитувальника скарг і психопатологічних симптомів, а також вимірювання вираженості больового синдрому за ВАШ і оцінювання рівня тривожності за особистісною шкалою проявів тривоги Тейлора. У найближчому періоді після оперативного втручання та призначення симптоматичної психофармакотерапії оцінювання динаміки проводили індивідуально з кожним пацієнтом протягом перших 2-8 тижнів лікування. Дослідження у віддаленому періоді проводили через 3 і 6 місяців після початку терапії. Для порівняння аналогічні дослідження проводили серед хворих на КА без психічних порушень (контрольна група - 25 пацієнтів).

Враховуючи провідну роль больового синдрому у хворих на КА в цілому і його тісний зв'язок із наявністю ГПР, простежили чітку динаміку цього показника, оціненого за ВАШ, у пацієнтів основної та контрольної груп. Середній рівень інтенсивності болю за ВАШ у хворих із ГПР на передопераційному етапі був удвічі вищий, ніж у пацієнтів без цих порушень $(63,4 \pm 1,3$ проти $32,4 \pm 1,5$ бала; $\mathrm{P}<0,001)$, а після оперативного втручання показник зменшився лише на 5,9 бала, або 9,3\%. У подальшому відмічено високі темпи редукції середнього показника інтенсивності болю в обох групах (від 43,5\% до 84,4\%). Це закономірний результат проведеного оперативного втручання з ендопротезування тазостегнового суглоба й ортопедичних реабілітаційних заходів. Одночасне проведення корекційних заходів щодо виявлених ГПР у хворих основної групи дозволило вже до шестимісячного строку спостереження суттєво зменшити вираженість больового синдрому та наблизити їх до рівнів пацієнтів контрольної групи. Зокрема, через три місяці після початку терапії інтенсивність болю у пацієнтів основної групи перевищувала таку в контролі в 1,7 раза $(\mathrm{P}<0,001)$, через 6 місяців - в 1,2 раза $(\mathrm{P}>0,10)$, через рік - в 1,1 раза $(\mathrm{P}>0,60)$.

\section{Обговорення}

Коксартроз має провідні позиції серед інших остеоартрозів, оскільки вражає найбільший суглоб у людському тілі та призводить до грубої інвалідизації хворих. Пацієнти з коксартрозом чутливіші до переживання відчуття болю, вони частіше звертаються за допомогою до спеціалістів, відвідують лікувальні установи, приймають більше лікарських засобів, зокрема знеболювальних, i важко піддаються корекції. Питання розвитку ГПР у цих пацієнтів хвилює багатьох спеціалістів не лише в Україні, а і за кордоном. Тривожні та депресивні розлади найчастіше супроводжують цю патологію та значною мірою впливають на перебіг основного захворювання та на якість життя пацієнтів. Останні дані закордонних досліджень підтверджують той факт, що тривога та депресія можуть змінювати больовий поріг. У той же час хронічний біль сам по собі може викликати чи посилювати занепокоєння та депресію, розвивається так зване порочне коло, яке може суттєво вплинути на перебіг хронічного захворювання (Axford et al., 2010). Виявлений і досліджений нами стійкий взаємозв'язок больового синдрому із наявністю ГПР підтверджує отримані результати багатьох вітчизняних і закордонних досліджень. Зокрема, у дослідженні Gerrits et al. (2014) вивчали вплив тривоги та депресії на симптоми остеоартрозу. Встановлено прямий вплив цих психопатологічних станів на больовий синдром, що був провідним проявом остеоартрозу. Дослідники повідомляють, що вираженість тривоги та депресії взаємопов'язані з болем в ураженому суглобі, а також із його інтенсивністю. А больовий синдром, у свою чергу, посилював прояви депресивної та тривожної симптоматики. Все це значно погіршує якість життя пацієнтів та їх соціальну активність (Sale et al., 2008; Gerrits et al., 2014).

Проведене дослідження виявило, що переважна більшість пацієнтів мала 41-60 років, тобто була в найбільш працездатному віці. Цей факт відіграє значну роль у проведенні лікувально-реабілітаційних заходів, тому що тривале та дороге лікування впливає на соціальну активність цих хворих, знижує трудову активність, що підтверджує виявлення в них симптомів ГПР порівняно з іншими віковими групами. Схожі результати отримані також в іноземних дослідженнях. Наприклад, Gignac et al. (2013) повідомляє, що пацієнти середнього віку (50,8 року) з остеоартрозом частіше скаржилися на знижений настрій чи відчуття тривоги, на відміну від хворих похилого віку (середній вік склав 67,8 року), що страждали на остеоартроз аналогічного ступеня тяжкості. Виявлена особливість описана авторами як переважне відчуття невдоволення та зниження якості життя внаслідок тяжкого захворювання в осіб середнього віку (Gignac et al., 2013).

Не викликає сумніву той факт, що у хворих з остеоартрозом, які потребують хірургічного лікування, частіше виявляються симптоми ГПР. Обстежені нами хворі перебували у відділенні ендопротезування, їм усім призначене оперативне втручання для заміни тазостегнового суглоба. Досить висока частка виявлених психопатологічних розладів серед цього контингенту хворих підтверджує дезадаптивний вплив хірургічного втручання. Kirkness et al. (2012) повідомляють, що великий депресивний розлад дуже поширений у пацієнтів, яким заплановане тотальне ендопротезування суглоба.

Що стосується лікувально-реабілітаційних заходів, доведена необхідність комплексного та індивідуального підходу до лікування цього контингенту хворих з урахуванням соматичних, психогенних і конституційних особливостей. Проведене дослідження виявило деякі труднощі та недоліки в лікувальних протоколах, що створює перепони для якісного та успішного видужання. Важливий саме комплексний підхід до лікування із залученням суміжних спеціалістів психіатричного профілю. Закордонні дослідники підтверджують факт, що лікарі загальносоматичного профілю частіше зосереджені винятково на фізичних аспектах остеоартрозу та не завжди враховують психічний стан хворого. Можлива причина - недостатність компетенцій у цій галузі та неможливість якісно дослідити психічні зміни при соматичному захворюванні (Turner and Kelly, 2000).

Для лікування ГПР у досліджуваних нами пацієнтів ми застосували психоосвітні та психотерапевтичні заходи (бесіда, лекція, аутотренінг), а також психофармакотерапію (транквілізатори, антидепресанти, нейролептики в малих і середніх терапевтичних дозах). Комплексний підхід мав позитивні результати відносно зниження проявів ГПР і, як наслідок, відмічене суттєве поліпшення переносимості больових відчуттів у цих хворих, що ще раз підтверджує досліджуваний взаємозв'язок. Як видно з багатьох закордонних досліджень, спеціалісти активно розробляють нові програми комплексного лікування. Доведено позитивний вплив на загальний стан хворого таких психотерапевтичних методик як терапія музикою та йога (Ottaviani et al., 2012; Middleton et al., 2013).

Таким чином, проведений аналіз роботи із вивчення проблеми взаємовпливу психічної та фізичної складової за остеоартрозу доводить актуальність вибраної тематики та окреслює шляхи подальшого вдосконалення діагностичних та корекційних програм.

\section{Висновки}

Граничні психічні порушення, що мають місце у хворих із тривалими соматичними захворюваннями, до яких, зокрема, належить КА, суттєво посилюють тяжкість стану, знижують адаптаційні можливості, впливаючи тим самим на перебіг i результат основного захворювання.

Переважання у пацієнтів із соматичними захворюваннями непсихотичних (граничних) форм психічних розладів значно ускладнює їх розпізнавання через неповну відповідність критеріям діагностики розгорнутого психіатричного захворювання. Досить часто в клінічній картині захворювання соматичні скарги та функціональні симптоми у пацієнтів із психопатологічними порушеннями (депресією, тривогою) настільки прева- 
люють, що лікарі-інтерністи навіть не припускають наявності у хворого психічного розладу.

Під час проведення курсів підвищення кваліфікації для лікарів загальносоматичного профілю необхідно робити акцент на вдосконаленні навичок своєчасно виявляти граничні психічні розлади, визначати їх тяжкість, а також направляти пацієнтів на консультацію до лікарів психотерапевтів та психіатрів.

Важлива необхідність призначення адекватної терапії виявлених психічних розладів у межах роботи з психічною сферою соматичного хворого, що дозволить знизити ризик рецидиву або загострення його хронічного захворювання, а також істотно вплине на зменшення тяжкості перебігу соматичної хвороби, зокрема інтенсивності больового синдрому.

Для виявлення психопатологічних порушень у соматичних хворих доцільно використовувати не тільки діагностичні критерії MKX-10, а й різні психометричні шкали та опитувальники для об'єктивізації клінічної симптоматики, дослідження вираженості проявів тривоги, депресії, невротичних розладів, особистісних характеристик пацієнтів, типів ставлення до хвороби тощо. Це дає можливість для глибшої диференційної діагностики психопатологічних станів, що перебігають зі схожою клінічною симптоматикою, але мають важливі відмінності у психологічній картині порушень. Застосування особистісних опитувальників дозволяє не тільки виявляти стрижньові структури пацієнта, що виконують ключову роль в його психічній дезадаптації, а i визначати мішені для психотерапевтичної роботи.

\section{References}

Ackerman, I. N., Bohensky, M. A., de Steiger, R., Brand, C. A., Eskelinen, A., Fenstad, A. M., Furnes, O., Graves, S. E., Haapakoski, J., Mäkelä, K., Mehnert, F., Nemes, S., Overgaard, S., Pedersen, A. B., \& Garellick, G. (2017). Lifetime risk of primary total hip replacement surgery for osteoarthritis from 2003-2013: A multi-national analysis using national registry data: International lifetime risk of total hip replacement for osteoarthritis. Arthritis Care and Research.

Axford, J., Butt, A., Heron, C., Hammond, J., Morgan, J., Alavi, A., Bolton, J., \& Bland, M. (2010). Prevalence of anxiety and depression in osteoarthritis: Use of the hospital anxiey and depression scale as a screening tool. Clinical Rheumatology, 29(11), 1277-1283.

Bair, M., Wu, J., Damush, T., Sutherland, J., \& Kroenke, K. (2008). Association of depression and anxiety alone and in combination with chronic musculoskeletal pain in primary care patients. Psychosomatic Medicine, 70(8), 890-897.

Beltman, M. W., Voshaar, R. C. O., \& Speckens, A. E. (2010). Cognitivebehavioural therapy for depression in people with a somatic disease: Meta-analysis of randomised controlled trials. The British Journal of Psychiatry, 197(1), 11-19.

Bokma, W. A., Batelaan, N. M., van Balkom, A. J. L. M., \& Penninx, B. W. J. H. (2017). Impact of anxiety and/or depressive disorders and chronic somatic diseases on disability and work impairment. Journal of Psychosomatic Research, 94, 10-16.

Calvo-Lobo, C., Vilar Fernández, J. M., Becerro-de-Bengoa-Vallejo, R., Losa-Iglesias, M. E., Rodríguez-Sanz, D., Palomo López, P., \& López López, D. (2017). Relationship of depression in participants with nonspecific acute or subacute low back pain and no-pain by age distribution. Journal of Pain Research, 10, 129-135.

Chaban, O. S., \& Khaustova, O. O. (2010). Terapiia khronichnoho alhichnoho syndromu u patsiientiv z nepsykhotychnymy depresyvnymy rozladamy i komorbidnoiu somatychnoiu patolohiieiu [Therapy of chronic algic syndrome in patients with non-psychotic depressive disorders and comorbid somatic pathology]. Ukrainskyi Visnyk Psykhonevrolohii, 18(1), 67-72 (in Ukrainian).

Cho, H. J., Morey, V., Kang, J. Y., Kim, K. W., \& Kim, T. K. (2015). Prevalence and risk factors of spine, shoulder, hand, hip, and knee osteoarthritis in community-dwelling koreans older than age 65 years. Clinical Orthopaedics and Related Research, 473(10), 3307-3314.

Chong, T., Don, D. W., Kao, M.-C., Wong, D., \& Mitra, R. (2013). The value of physical examination in the diagnosis of hip osteoarthritis. Journal of Back and Musculoskeletal Rehabilitation, 26(4), 397-400.

Danilov, A. B. \& Danilov, A. B. (2010). Bol': Patogenez i lechenie [Pain: Pathogenesis and treatment]. Rossiyskiy Zhurnal Boli, 2, 35-39 (in Russian).

Duffy, P. J., Masri, B. A., Garbuz, D. S., \& Duncan, C. P. (2005). Evaluation of patients with pain following total hip replacement. The Journal of Bone and Joint Surgery. American Volume, 87(11), 2566-2575.
Gerrits, M. M., van Oppen, P., Leone, S. S., van Marwijk, H. W., van der Horst, H. E., \& Penninx, B. W. (2014). Pain, not chronic disease, is associated with the recurrence of depressive and anxiety disorders. BMC Psychiatry, 14(1).

Gignac, M. A. M., Backman, C. L., Davis, A. M., Lacaille, D., Cao, X., \& Badley, E. M. (2013). Social role participation and the life course in healthy adults and individuals with osteoarthritis: Are we overlooking the impact on the middle-aged? Social Science and Medicine, 81, 87-93.

Hardcastle, S. A., Dieppe, P., Gregson, C. L., Hunter, D., Thomas, G. E. R., Arden, N. K., Spector, T. D., Hart, D. J., Laugharne, M. J., Clague, G. A., Edwards, M. H., Dennison, E. M., Cooper, C., Williams, M., Davey Smith, G., \& Tobias, J. H. (2014). Prevalence of radiographic hip osteoarthritis is increased in high bone mass. Osteoarthritis and Cartilage, 22(8), 1120-1128.

Hawker, G. A., Gignac, M. A. M., Badley, E., Davis, A. M., French, M. R., Li, Y., Perruccio, A. V., Power, J. D., Sale, J., \& Lou, W. (2011). A longitudinal study to explain the pain-depression link in older adults with osteoarthritis. Arthritis Care and Research, 63(10), 1382-1390.

Kc, R., Li, X., Forsyth, C. B., Voigt, R. M., Summa, K. C., Vitaterna, M. H., Tryniszewska, B., Keshavarzian, A., Turek, F. W., Meng, Q.-J., \& Im, H.-J. (2015). Osteoarthritis-like pathologic changes in the knee joint induced by environmental disruption of circadian rhythms is potentiated by a high-fat diet. Scientific Reports, 5, 16896.

Kirkness, C. S., McAdam-Marx, C., Unni, S., Young, J., Ye, X., Chandran, A., Peters, C. L., \& Asche, C. V. (2012). Characterization of patients undergoing total knee arthroplasty in a real-world setting and painrelated medication prescriptions for management of postoperative pain. Journal of Pain and Palliative Care Pharmacotherapy, 26(4), 326-333.

Lawrence, R. C., Felson, D. T., Helmick, C. G., Arnold, L. M., Choi, H., Deyo, R. A., Gabriel, S., Hirsch, R., Hochberg, M. C., Hunder, G. G., Jordan, J. M., Katz, J. N., Kremers, H. M., \& Wolfe, F. (2008). Estimates of the prevalence of arthritis and other rheumatic conditions in the United States: Part II. Arthritis \& Rheumatism, 58(1), 26-35.

Loskutov, A. E. (2010). Endoprotezirovanie tazobedrennogo sustava [Hip arthroplasty]. Lira, Dnipropetrovsk (in Russian).

Makolkin, V. I., Pak, I. V., \& Men'shikova, I. V. (2007). Koksartroz: Voprosyi etiologii, epidemiologii, klinicheskih proyavleniy i novyih podhodov $\mathrm{k}$ lecheniyu [Coxarthrosis: Etiology, epidemiology, clinical manifestations and new approaches to therapy]. Terapevticheskii Arkhiv, 79(1), 81-85 (in Russian).

Matcham, F., Rayner, L., Steer, S., \& Hotopf, M. (2014). The prevalence of depression in rheumatoid arthritis: A systematic review and metaanalysis: Reply. Rheumatology (Oxford, England), 53(3), 578-579.

Middleton, K. R., Ward, M. M., Haaz, S., Velummylum, S., Fike, A., Acevedo, A. T., Tataw-Ayuketah, G., Dietz, L., Mittleman, B. B., \& Wallen, G. R. (2013). A pilot study of yoga as self-care for arthritis in minority communities. Health and Quality of Life Outcomes, 11, 55.

Mújica Mota, R. E. (2013). Cost-effectiveness analysis of early versus late total hip replacement in Italy. Value in Health, 16(2), 267-279.

Munce, S., \& Stewart, D. (2007). Gender differences in depression and chronic pain conditions in a national epidemiologic survey. Psychosomatics, 48(5), 394-399.

Nassonova, V. A., Mendel, O. I., Denisov, L. N., Vertkin, A. L., Alekseyeva, L. I., \& Naumov, A. V. (2011). Osteoartroz i ozhirenie: Kliniko-patogeneticheskie vzaimosvjazi [Osteoarthrosis and obesity: Clinical and pathogenetic associations]. Profilakticheskaya Meditsina, 1, 29-37 (in Russian).

O’Connor, K., Vizcaino, M., Ibarra, J. M., Balcazar, H., Perez, E., Flores, L., \& Anders, R. L. (2015). Multimorbidity in a mexican community: Secondary analysis of chronic illness and depression outcomes. International Journal of Nursing, 2(1), 35-47.

Ottaviani, S., Bernard, J.-L., Jean-Luc, B., Bardin, T., Thomas, B., Richette, P., \& Pascal, R. (2012). Effect of music on anxiety and pain during joint lavage for knee osteoarthritis. Clinical Rheumatology, 31(3), 531-534.

Poulsen, E., Christensen, H. W., Overgaard, S., \& Hartvigsen, J. (2012). Prevalence of hip osteoarthritis in chiropractic practice in Denmark: A descriptive cross-sectional and prospective study. Journal of Manipulative and Physiological Therapeutics, 35(4), 263-271.

Rahman, M. M., Kopec, J. A., Goldsmith, C. H., Anis, A. H., \& Cibere, J. (2016). Validation of administrative osteoarthritis diagnosis using a clinical and radiological population-based cohort. International Journal of Rheumatology, 2016, 1-7.

Rebrov, B. A., Blaginina, I. I., \& Rebrova, O. A. (2011). K voprosu o svjazi hronicheskogo bolevogo sindroma i trevozhno-depressivnyh rasstrojstv u bol'nyh terapevticheskogo profilja [To the question of the relationship of chronic pain syndrome and anxiety depressive disorders in patients of therapeutic profile]. Bol', Sustavy, Pozvonochnik, 1(2), 83-87 (in Russian).

Riediger, W., Doering, S., \& Krismer, M. (2010). Depression and somatisation influence the outcome of total hip replacement. International Orthopaedics, 34(1), 13-18. 
Rodic, D., Meyer, A. H., \& Meinlschmidt, G. (2015). The association between depressive symptoms and physical diseases in Switzerland: A crosssectional general population study. Frontiers in Public Health, 3, 47.

Sale, J. E. M., Gignac, M., \& Hawker, G. (2008). The relationship between disease symptoms, life events, coping and treatment, and depression among older adults with osteoarthritis. The Journal of Rheumatology, 35(2), 335-342.

Sharma, A., Kudesia, P., Shi, Q., \& Gandhi, R. (2016). Anxiety and depression in patients with osteoarthritis: Impact and management challenges. Open Access Rheumatology: Research and Reviews, 8, 103-113.

Sharma, L., \& Berenbaum, F. (Eds.). (2007). Osteoarthritis: A companion to rheumatology. Mosby, Philadelphia.

Strine, T. W., Mokdad, A. H., Balluz, L. S., Gonzalez, O., Crider, R., Berry, J. T., \& Kroenke, K. (2008). Depression and anxiety in the united states:
Findings from the 2006 behavioral risk factor surveillance system. Psychiatric services, 59(12), 1383-1390.

Tonelli, S. M., Rakel, B. A., Cooper, N. A., Angstom, W. L., \& Sluka, K. A (2011). Women with knee osteoarthritis have more pain and poorer function than men, but similar physical activity prior to total knee replacement. Biology of Sex Differences, 2, 12.

Tukker, A., Visscher, T., \& Picavet, H. (2008). Overweight and health problems of the lower extremities: Osteoarthritis, pain and disability. Public Health Nutrition, 1.

Turner, J., \& Kelly, B. (2000). Emotional dimensions of chronic disease. The Western Journal of Medicine, 172(2), 124-128.

Zagorodniy, N. V. (2011). Endoprotezirovanie tazobedrennogo sustava. Osnovyi i praktika [Hip arthroplasty. Fundamentals and practice]. GeotarMedia, Moscow (in Russian). 